\section{Effect of Boron Supply on the Sugars, Soluble in 80 per cent Ethanol, in Flax Seedlings}

FLAX plants (Linum usitatissimum var. Ventnor) were grown in nutrient cultures supplied with increasing concentrations of boron. The methods were such that an addition of 0.001 p.p.m. boron to the basal medium produced a large growth response. After four weeks the plants were harvested and weighed (Fig. I). The 0 p.p.m. boron plants grew very little throughout the four weeks; both these and the 0.001 p.p.m. boron plants showed typical deficiency symptoms in stems and roots.

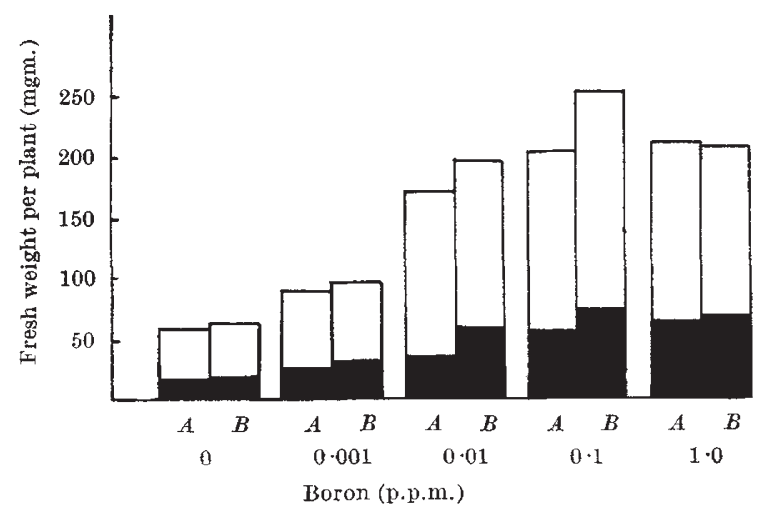

Fig. 1. Fresh weight of flax plants grown at increasing levels of boron supply. White, tops; black, roots

The plants of each treatment (which was duplicated) were divided into stem tips, the remainder of stem and leaves, and roots. These tissues were extracted with 85 per cent ethanol. Extracts, usually each equivalent to $40 \mathrm{mgm}$. fresh weight, were spotted on to No. 3 Whatman paper, and the chromatograms were eluted with a pyridine/ethyl acetate/water $(80: 20: 10)$. Two chromatograms were run for each set of extracts. One was developed with silver nitrate and ethanolic sodium hydroxide; from the other the portions of paper corresponding to the sucrose, glucose and fructose spots were eluted and the sugars estimated by the method of Wager ${ }^{1}$.

Sucrose, glucose and fructose were the principal sugars detected. Qualitative examination of the chromatogram (Fig. 2) showed no evidence that the stem tips and roots of boron-deficient plants were carbohydrate-deficient. The results of the quantitative analyses confirm this (Table 1).

Table 1. THE EFFret OF BORON ON THE Distribution OF SUaARS

\begin{tabular}{|c|c|c|c|c|c|c|}
\hline \multirow{2}{*}{\multicolumn{2}{|c|}{ P.p.m. boron in culture }} & $0^{*}$ & $0.001^{*}$ & 0.01 & $0 \cdot 1$ & $1 \cdot 0$ \\
\hline & & \multicolumn{5}{|c|}{$\begin{array}{l}\text { Sugar concentration (mgm./gm. } \\
\text { fresh weight) }\end{array}$} \\
\hline Stem tips & $\begin{array}{l}\text { Sucrose } \\
\text { Glucose } \\
\text { Fructose }\end{array}$ & $\begin{array}{l}0.90 \\
3.00 \\
1.98\end{array}$ & $\begin{array}{l}1 \cdot 85 \\
2 \cdot 90 \\
2 \cdot 48\end{array}$ & $\begin{array}{l}2 \cdot 18 \\
1.55 \\
0.67\end{array}$ & $\begin{array}{l}2 \cdot 00 \\
1 \cdot 10 \\
0 \cdot 32\end{array}$ & $\begin{array}{l}1 \cdot 57 \\
1 \cdot 14 \\
0.39\end{array}$ \\
\hline $\begin{array}{l}\text { Remainder of } \\
\text { stem and } \\
\text { leaves }\end{array}$ & $\begin{array}{l}\text { Sucrose } \\
\text { Glucose } \\
\text { Fructose }\end{array}$ & $\begin{array}{l}0.41 \\
1.75 \\
1.00\end{array}$ & $\begin{array}{l}0 \cdot 13 \\
1 \cdot 40 \\
0 \cdot 85\end{array}$ & $\begin{array}{l}0 \cdot 37 \\
0 \cdot 73 \\
0 \cdot 79\end{array}$ & $\begin{array}{l}0 \cdot 41 \\
1 \cdot 40 \\
0 \cdot 73\end{array}$ & $\begin{array}{l}0 \cdot 38 \\
1 \cdot 00 \\
0 \cdot 30\end{array}$ \\
\hline Roots & $\begin{array}{l}\text { Sucrose } \\
\text { Glucose } \\
\text { Fructose }\end{array}$ & $\begin{array}{l}1 \cdot 60 \\
1.54\end{array}$ & $\begin{array}{l}\text { No1 } \\
1 \cdot 41^{1} \\
1 \cdot 18\end{array}$ & $\begin{array}{l}\text { e detec } \\
0.95 \\
0.57\end{array}$ & $\begin{array}{l}\text { ted } \\
0 \cdot 60 \\
0.54\end{array}$ & $\begin{array}{l}0.61 \\
0.19\end{array}$ \\
\hline
\end{tabular}

* Plants showing boron-deficiency symptoms.

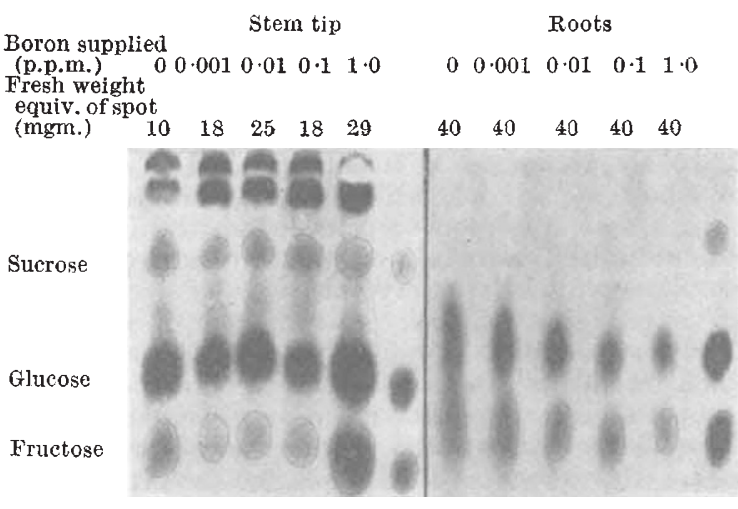

Tig. 2. The sugars in the stem tips and roots of flax plants grown at increasing levels of boron supply

Boron deficiency appears to depress the sucrose, but not the fructose or glucose content of flax stem tips. The remainder of the stems and leaves of borondeficient plants in general contain more of the three sugars, expressed on the fresh weight basis, than normal plants, while in flax roots boron deficiency results in the accumulation of glucose and fructose.

These results do not support the hypothesis ${ }^{2}, 3$ that the cessation of growth in boron-deficient plants may be attributed to a carbohydrate deficiency in shoot tips and roots. It has further been demon. strated in this laboratory that excised flax roots grown in a specially purified sterile medium, which included 4 per cent sucrose, ceased to grow after $48 \mathrm{hr}$. in the absence of boron.

I wish to thank Dr. K. S. Rowan for advice on matters of technique.

T. F. Neales

Botany School,

University of Melbourne,

Victoria, Australia.

Nov. 21.

${ }^{1}$ Wager, H. G., Analyst, 79, 34 (1954).

2 Gaueh, H. G., and Dugger, W. M., Bull. Md. Agric. Exp. Sta. A.so ('Technical), (1954).

${ }^{3}$ Gauch, H. G., and Dugger, W. M., Plant Physiol., 28, 457 (1953).

\section{GEOLOGY and PHYSIOGRAPHY}

\section{Trap-Shotten Rock from the Biligirirangan Hills, Mysore State, India}

Charnockitic rocks have been developed over a wide area in the southern part of the State of Mysore in India. The typical charnockites are found in isolated patches of varying dimensions. The largest of these occurrences is in the Biligirirangan Hills, where a fairly continuous mass of charnockite extending more than 25 miles forms this mountainous tract which lies between $11^{\circ} 40^{\prime}$ and $12^{\circ} \mathrm{N}$. In this region peaks of more than $5,000 \mathrm{ft}$. are common on the ranges, which generally trend in a north to south direction.

For the purposes of this communication, it is not necessary to describe the petrography or the rock associations of this interesting area. Attention is 